eine viel schwächere Verdichtung der Peribele schliessen als nach dem Gesetze, welches für Cometen angenommen wird.

8. Alle diese Punkte finden eine wahrscheinlichere Erklärungr unter Vorausset»ung stark ausgeprägt hyperbolischer Bahnen. als fïr parabolische. -

Es ist selbstverstindlich, dass sich diese Betrachtnngen nur auf Meteore beziehen, welche durch ilır Auttreten die mittlere Häufigkeit bestimmen, nicht auf besondere Ströme. Wenn gewichtige Momente dafür sprechen, einzelnen Meteorströmen parabolische Bahnen und den Zusammenhang mit den Cometen zuzus chreiben, so ist mir andererseits kein Grund bekannt, aus welchem die Einheit der Geschwindigkeit für alle Me- teore a priori gefolgert werden müsste. Leberdies hat selbst Schiaparelli (a. a. O. 7. Note p. 261) gezeigt, dass unter Voraussetzungen, welche den reellen Verhälnissen wahrscheinlich sehr nahe kommen, Bahnen von ausge. prägt hyperbolischem Character für die zu uns gelangenden Metcore eigentlich die wahrscheinlicheren sind.

Der hier besprochene Gegenstand verdient in seiuen Einzelheiten mehr Aufmerksamkeit als ihm bisher zu Theil wurde, und es widre wünschenswerth. dass unter selır verschiedenen Polhölıen die Beobachtungen etwas systematischer als bisher vorgenommen und mit Sor. falt reducirt würden.

Brüun, im Scptember 1878.

\title{
Sur la force qui produit les queues des comètes.
}

En calculant pour les comètes suffisament observées la force $\mathrm{I}-\mu$, qui est nécessaire pour le développement de leurs queues, je suis venu à la conclusion que cette force se présente par sa valeur sous trois types différents, qu'on voit dans la table suivante. - Dans cette table la lettre $A$ désigne, que le développement de la queue a eu lieu avant le passage du périhélie; la lettre $P$ se rapporte au développement après ce passage. Dans la colonne $r$ on trouve les rayons vecteurs correspondants au milieu du phénomène. La table donne enfin la direction du mouvement des comètes et les éléments de leurs orbites. L'inspection de ces nombres nous montre, que les types ne sont pas en dépendence ni de la direction du mouvement, ni de la distance en périhélie, ni des autres éléments.

Pour les queues 'du troisième type, qui sont toujours courtes et estompées, le calcul ne peut donner que des résultats approximatifs et c'est pourquoi les valeurs de I $-\because$ pour ce type sont mises en parenthèses.

La différence entre les types semble indiquer la différence dans les propriétés physico-chimiques de la matière des queues; différences entre les valeurs d'un même type peuvent provenir des erreurs d'observation, mais principalement elles doivent dépendre aussi de quelques variétés dans la substance de chaque type.

\begin{tabular}{|c|c|c|c|c|c|c|c|c|c|c|}
\hline & & ype & & & & & & & & \\
\hline comètes : & I & II & III & $r$ & & Mouv. & $\Omega$ & $i$ & $q$ & $\pi$ \\
\hline $157 \%$ & - & 0.8 & $(0.2)$ & 1.1 & $\mathbf{P}$ & $\mathbf{R}$ & $25^{\circ}$ & $75^{\circ}$ & 0.18 & $130^{0}$ \\
\hline $1618_{3}$ & - & 0.6 & 一 & 1.1 & $\mathbf{P}$ & D & 76 & 37 & o 39 & 3 \\
\hline 1665 & 12 & - & - & $0 . \overline{5}$ & $\mathbf{A}$ & $\mathrm{R}$ & 228 & 76 & 0.10 & 72 \\
\hline 1811 & 11 & - & - & 1.7 & $\mathrm{P}$ & $\mathbf{R}$ & 140 & 73 & 1.04 & 75 \\
\hline $1830 ̄$ & 10 & - & $(0.2)$ & 0.9 & A & $\mathbf{R}$ & 55 & 18 & $0 . \check{5} 9$ & 305 \\
\hline 1844 & - & - & $(0.1)$ & 0.9 & $\mathbf{P}$ & D & 118 & 46 & 0.25 & 296 \\
\hline $1853_{8}$ & 12 & - & (0.1) & 0.3 & A & D & 141 & 62 & 0.31 & 311 \\
\hline $18 \overline{8} 8$ & 10 & 0.6 & - & 0.6 & $\mathbf{P}$ & $\mathbf{R}$ & 165 & 63 & 0.58 & $\mathbf{3 6}$ \\
\hline $1860_{3}$ & - & 0.6 & - & 0.6 & $\mathbf{P}$ & D & 85 & 79 & 0.29 & 162 \\
\hline $1861_{2}$ & 12 & - & 0.2 & 1.3 & $\mathbf{P}$ & D & 279 & 86 & 0.82 & 249 \\
\hline $1862_{2}$ & 11 & - & $(0.1)$ & 1.0 & $\mathbf{A}-\mathbf{P}$ & $\mathbf{R}$ & 137 & 66 & 0.96 & 290 \\
\hline $1874^{\mathrm{c}}$ & - & 0.9 & - & 0.9 & $\mathbf{A}-\mathbf{P}$ & D & 119 & 66 & 0.67 & 271 \\
\hline $1877^{b}$ & 9 & - & $(0.1)$ & 1.0 & $\underline{\mathbf{P}}$ & $\mathbf{R}$ & 317 & 59 & 0.95 & 19 \\
\hline
\end{tabular}


La présence des deux types dans une comète montre naturellement la duplicité de sa queue. Quant aux petites queues dirigées vers le soleil, - elles sont omises dans notre table, parceque j'ai montré déjà (Annales de l'obs. de Moscou, Vol. III, livr. I, pg. 4I), que ces queues peuvent être expliquées sans admission de quelque force - par l'impulsion des émissions sur la masse peu solide des comètes.
Les calculs qui confirment ma division en types, - on les trouvera dans les annales publiées de notre observatoire, ainsi que dans les deux livraisons du cinquième volume, qui est déjà sous presse.

\section{Th. Breuichin,}

Directeur de l'obs, de Moscou.

1878, 18. September.

\section{Schreiben des Herrn Prof. Watson an den Herausgeber.}

I have received detinite information from those who observed the recent total eclipse of the sun at the same station with me, in regard to the question which I raised as to the possibility of the pointing of my telescope havinir been disturbed by the wind, at the close of the observations, when it was directed to the object whici I designated by (b). and whose place as shown by the circles was conmunicated to you in a previous letter. For the reasons stated, I did not verify the pointing, in this case. after the position was marked on the circles, and this fact was stated in order that astronomers might be fully adrised of every circumstance connected with these observations.

Professor Newcumb, Cummander Sampson U. S. N., and Lieutenant Bowman U.S. N., were observin's near me, and any gust of wind which could disturb my iustrument would certainly have disturbed theirs, because ny telescope was more completely sheltered than any of the others. Each of these gentlemen has informed me that there was no disturbance of lis iustrument by the wind during the totality of the eclipse. Professor Newcomb's telescope was pointed at the same time upon what proved to be a fixed star north of the sun, aud lis circle readings showed no disturbance of any kind. I find further that the direction of the wind was such that its force was wholly to change the pointing in declination, if at all, and this was securely clamped. The position on the hour circle was marked first, and but a moment elapsed in passing from the eye-piece to the place were this was done. In order to find what amount of force would be necessary to clange the pointing in the case under consideration, I have made an actual experiment with the same telescope, clamped as it was then, and the result is conclusive that the danger of error on this account, which $I$ at first thought to be possible. has no significance whatever.

1 have also examiued with the same telescope and magnifying power used in the eclipse observatior $s$, the stars in this part of Cancer, with the moon in the western sky and the bright twilight in the east, so as to obtain, as nearly as possible, the conditions of skyillumination which existed at the time of the eclipse. I have a very distinct recollection in respect to the brilliancy of the stars which I saw, and by observing when the approaching daylight reduced the lay of certain stars wlich were east of the sun at the time of the total eclipse, so as to be just visible in the telescopo as they were then, I have been enabled to form a still more definite opinion of the relative brilliancy of $A$ Cancri, the two new objects which I observed, and $\zeta$ Cancri. The fainter of the two planets, that near $\theta$ Cancri, was certainly brighter than $\zeta$ Cancri, and much more than a magnitude brighter than its neighboring star. I am inclined to think that the planet $(a)$ should be classed as good fourth magnitude and that the planet ( $b$ ) should be classed as third magnitude, at the time of the observations on July 24.

Ann Arbor 1 s78 Sept. 17.

James C. Watson.

Zu Nr. 2223. G. v. Niessl. Ueber die tägliche Variation der Sternschnuppen. 225. - Th. Bredichin. Sur la force qui produit les queues des cometes. 237. - Fames $C$. Watson. Schreiben an den Herausgeber. 239. 